\title{
ПРОБЛЕМА «АВТОР-ГЕРОЙ» У КОНТЕКСТІ СТРУКТУРУВАННЯ МОДЕЛІ АВТОРСЬКОЇ СВІДОМОСТІ (на прикладі драми Юрія Косача «Скорбна симфонія»)
}

Розглянуто особливості проблеми самоідентичності у драмі Юрія Косача «Скорбна симфонія». Зокрема, увагу зосереджено на взаємоієрархічності історичної пам'яті та історичної свідомості, їх консолідуючому значенні у формуванні ідентичності української нації в умовах еміграції. Відзначено, що формою авторської ідентичності у творчій діяльності та ідентичності читача в процесі рецепції є образ героя, який виступає як образна картина і проект уявної особистості.

Ключові слова: автор, герой, драма, ідентичність, свідомість, текст.

Останнім часом в українській біографістиці стає все більш помітним інтерес дослідників до застосування психологічних методів для аналізу творчості письменника. Йдеться про увиразнення психічної сутності в особистості митця, тобто про динаміку розвитку психіки від їі первинних імпульсів через перетворення i розвиток. У такий спосіб - iз взаємодії натури i долі, внутрішніх сил i зовнішніх чинників - 3’ясовується психологічна позиція особистості, що сприяє специфічному вияву художнього обдарування, нерідко зумовлює тематику i проблематику творчості.

Одним із найважливіших компонентів психоаналітичної моделі творчого процесу є почуття провини і компенсації. Письменник пише твір як власну сповідь і водночас дає можливість реципієнту, сприймаючи твір, вийти за межі бажань, які можна реалізувати у повсякденному житті. Певним чином, позиція митця i реципієнта збігаються. В акті творчості, i акті сприймання митець і реципієнт реалізують свої прагнення, знаходять новий спосіб спілкування, організації інтерсуб'єктивної сфери: зрозуміти себе за допомогою іншого. Продукт творчого акту являє собою дещо, що різниться 3 реальністю навіть у сфері бажань. Тобто бажання та прагнення, які 
реалізуються в мистецтві, визнаються як такі, що виходять за межі «природних потреб».

Драматичний твір Юрія Косача «Скорбна симфонія», присвячений проблемі пошуків самоідентичності митцем у межовій ситуації буття, зображує протиборство двох душ, двох ідентичностей. Драматична дія розгортається в 1812 році перед інвазією наполеонівської армії й початком франко-російської війни. Головний герой, Дмитро Бортнянський, на той час залишає посаду керівника придворної співочої капели і поринає у похмуру пасивну депресію, живе в убогій частині міста у відчуженні не лише від галасу світського життя, а й від людей загалом. Водночас у кількох ретроспективних сценах реципієнт знайомиться 3 Італією другої половини 1770 років. На той час Бортнянський був уже відомим композитором, адже в 1776 році в театрі «Сан-Бенедетто» була поставлена його опера «Креонт», яка принесла композитору неабияку славу. Проте митець вирішує повернутися 3 Італії в Російську імперію і залишитися в Петербурзі. Здебільшого біографи Бортнянського подають скупі факти про життя композитора напередодні війни 1812 року, тому питання, наскільки Юрій Косач (відомий, з одного боку, прискіпливістю у дослідженнях раритетних історичних джерел та документів, а 3 іншого - белетрист, наділений неабиякою творчою фантазією) дотримується історичної правди, залишається відкритим.

У «Скорбній симфонії» Дмитро Бортнянський не може знайти вихід iз ситуації вибору, яка постає перед ним як стіна, що відкидає його назад, до себе, до екзистенції. Депресія, сумніви героя - це значною мірою настрій митця, який на схилі літ змагається 3 почуттями вимріяної, та ніколи не написаної величної симфонії. У критичний час Бортнянський мусить осягнути висоти духу i нести відповідальність за власний вибір. Психологічний автопортрет душевного стану митця в межовій ситуації передбачає страждання, екзистенцію «дійсного» внутрішнього буття як наслідок осяяння. Хвилеподібний плин свідомості чергується 3 
філософськими узагальненнями. Роздуми про особисте життя поєднуються 3 аналізом історичної долі українського народу. Збентежений, під тиском непорозумінь, герой втікає від зовнішніх обставин у власний світ, але й там не знаходить душевного спокою.

Художнє розгортання теми пошуків себе митцем реалізується завдяки алегоричності. Сюжет драматичного твору має циклічну структуру, адже автор занурює героя у вир випробувань (слава, багатство, самоусвідомлення), що реалізуються автором завдяки введенню образів жінок. Інтертекстуальне прочитання творів Косача дає право стверджувати, що жіночі образи «Скорбної симфонії», як і герої класицистичної драми, наділені іменамихарактеристиками: княжна Дараган, Чорна пані, Санька. Конфлікт між цими групами персонажів драми - це відображення внутрішнього конфлікту головного героя між прагматизмом і жертовністю.

У критичній ситуації вибору рішення, що визначило його подальшу долю, перед Бортнянським постають дві демонічні жінки: княжна Дараган та Чорна пані. Обидва образи відомі за іншими творами Юрія Косача, і тому реципієнту вже не складно декодувати їх основне символічне значення.

Образ Чорної пані вперше з'являється в однойменній збірці 1931 року. Ліричному герою збірки ввижається загадковий доктор Ікс, який докоряє йому за різні мистецькі та моральні огріхи (облудність текстів, нещирість, страх сказати правду читачеві). Водночас ці прояви совісті нейтралізує привид красивої Чорної пані, яка закликає його забути про все i насолоджуватися існуванням. Аналіз специфіки відображення Ю.Косачем дійсності із застосуванням філософських гедоністичних критеріїв сприяє глибшому розумінню характеру художнього усвідомлення письменником проблем особистості.

Поняття задоволення - універсальна категорія культури, яка має відмінності в різних картинах світу. У кожного народу є власні звички, типові ситуації, які пов'язані з отриманням задоволення. Вищою насолодою і гедоніста, i аскета визнавався оспіваний античною думкою стан 
безпристрасного спокою, що в різних контекстах виражав або поняттями гедоністичної і стоїчної лексики: «атараксія» (безтурботність душі), «апонія» (відсутність тілесного страждання), «апатія» (безпристрасність), Принцип помірності став основним в античній культурі, на ньому основувалися i гедоністична, і аскетична традиції. У першому випадку помірність була умовою досягнення стану насолоди й уникнення задоволень, що призводять до страждань. У другому - способом досягнення чесноти, запорукою реалізації поставленої мети. Але в обох випадках принцип помірності дозволяв зняти напруження пристрастей, звести їх до певної усередненої норми. Античні вчення гедонізму й аскетизму були двома способами досягнення людиною, по суті, однієї і тієї ж мети - незалежності від зовнішнього світу, звільнення душі і досягнення нею блаженства.

У «Скорбній симфонії» функція й символічний зміст спокуси Чорної пані також спрямовані на гедоністичну насолоду з безперечним моральним компромісом, а композитор намагається досягти примарної мети творення «великої музики», присвятивши себе службі на благо імперії, що поглинула й поневолила його батьківщину. Головний герой драми уособлює душевну дилему, перед якою постали більшість українських митців XVIII й початку XIX століття, які були змушені шукати кар'єри й визнання в чужій столиці. Сам драматург зазначає: «А що було діяти Україні? «Пропащий час», говорив М. Драгоманов. Нi, професоре, це ще не був пропащий час. Це був реалістичний світогляд нащадків козацького барокко, які знали, що «головою муру не проб'єш». Були, звичайно, гедонізм, сервілізм. Але були і Г. Сковорода, i сяйна плеяда наших учених, митців [...]. Симбіоз довершувався прискорено, але й Україна не була пустелею. На жаль, не всі вони дивились на Київ, а на Петербург, бо там була кар'єра і славетність» $[3,185]$.

Концептуальний діалогізм має циклічний характер: Косача цікавить процес, а не результат, метою $є$ «вільний вибір», шлях, а не підсумок; сенс полягає у внутрішній духовній дії індивіда. Драматург, засвоївши 
гедоністичну філософію Епікура, намагався створити образ особистості, яка вбачає сенс життя в самопізнанні.

Дослідження динаміки особистості крізь призму самосвідомості, де індивід проходить шлях від нонконформізму до конформізму, дало можливість визначити певні модерністичні конотації у драмі Косача. Культура напруженого пошуку письменника у сфері зіткнення особистості та системи, де гідність людини та іiі право вільно виражати себе повністю нівелюються, відображає проблему екзистенційного страждання, а також зображує проблеми культури першої половини XIX століття.

Також не можна заперечувати того факту, що у «Скорбній симфонії» драматург свідомо інверсує свою біографію у напрямі життєвого шляху головного героя твору. Позиції автора й героя виявляють ознаки тотожності, адже образ Бортнянського можна сприймати як проекцію життєвого вибору самого Косача. «У дійсному житті Юрій Косач вибрав «шлях чорної пані» шлях відмови від душевної і моральної дисципліни, од щирости супроти читачів і супроти себе самого» $[4,266]$. Адже відомо, що, знаючи історію і сталінських, і подальших репресій, письменник під час перебування в НьюЙорку співпрацював із радянською владою. «А у 1973 р. у Києві, всупереч хвилям арештів і безпощадному розгромові української інтелігенції, виголошувати пеани на честь «Великого Жовтня» та «радянського ладу», які то, мовляв, повернули спадщину його славетної родички, Лесі Українки, «великому й новому союзові народів...» $[4,266]$.

Отож, у драматичному творі автор постає модусом «іншого» існування, естетично перетвореним суб'єктом, а тому важко визначити, коли перед реципієнтом з'являється автентичне авторське «я», а також неможливо до кінця збагнути іншу, «чужу» свідомість. 3 огляду на це варто розглядати авторську свідомість як складну метатекстуальну категорію, адже наближення до автора відбувається «через» текст і «з-поза» тексту. Під «авторською свідомістю» розуміємо цілісну функціональну систему, що передбачає тісний взаємозв'язок психологічних (емоційних, інтелектуальних 
тощо) структур свідомості письменника, його внутрішнього та прихованого життя, зі структурами наративними. Це поняття, з одного боку, завдяки існуванню позатекстових чинників охоплює «біографічного автора», а 3 іншого - через текстуальний простір апелює до лімінального автора. Ці «автори» формують у тексті образ «імпліцитного автора», партнером якого є імпліцитний читач. Імпліцитним автором прийнято вважати текстуальну конструкцію, яка, з одного боку, не має чіткого оформлення, існує лише віртуально (як сукупність усіх значень), а 3 іншого - ще не позначена суб’єктивністю читача. У процесі читання імпліцитний автор перетворюється в «образ автора», який витворений на основі прочитаного тексту. Поєднаний 3 інформацією про автора-творця, яку, ймовірно, має реальний читач, цей образ трансформується в автора. Таке трактування терміна «автор» $\epsilon$ найбільш обгрунтованим, адже поінформований читач мимоволі залучатиме до витвореного (через текст) у своїй свідомості образу «позатекстуальні» знання про емпіричну особу письменника.

Якщо у драматичному творі Косача Бортнянський обирає шлях національної самоідентичності, то в реальному житті сам автор піддається впливові «чорної пані» та обирає гедоністичну насолоду. «Гедоністична насолода із кабальною послідовністю приносила Косачеві злидні, страждання та відчуженість від оточення» $[4,266]$. Адже, як відомо, у другій половині п’ятдесятих років драматург почав регулярно друкувати у своєму журналі «За синім океаном» різкі (іноді істеричні) напади на українську еміграцію, що зумовило відразу суспільного оточення, в якому він до того часу жив та творив. «Згодом (коли він вже не був практично корисним) Косача покинули його радянські «партнери. Більшість останніх років життя Косач дожив на суспільному дні: серед наркоманів, повій і злочинців» $[4,266]$.

Драматичний твір не є відтворенням реальної біографії письменника, а відштовхуванням від неї - компенсацією того, що не здійснилося в реальному житті. 3 огляду на це для аналізу драматичного твору варто залучати не біографічний контекст, а психоаналітичний. Адже, на думку 
3. Фройда, за допомогою творчості митець розкриває свої фантазії, тим самим реалізує нездійснені власні бажання. Він ніби підбирає такі образи у власному несвідомому, які б могли розкрити його інтимні переживання та пригнічені бажання. Альфред Адлер визначає «компенсацію» як засіб подолання неповноцінності, засіб здобуття коректної моральної свободи. Вчений наголошував на ролі соціальних чинників, а характер людини, на його думку, будується відповідно до його «життєвого стилю», який являє собою «систему цілеспрямованих прагнень, у яких реалізується потреба в перевазі, вищості та самоствердженні, саме такі потреби виступають компенсацією комплексу неповноцінності» [1, 110]. На основі комплексу неповноцінності розвивається компенсаторний комплекс переваги. Якщо обидва комплекси надмірно розвинені, вони сприяють самовилученню людини 3 корисного життя. Але наповнені соціальним змістом i проявляючись адекватно ситуації, вони постають як сигнальні орієнтири. Кожна людина на основі свого прототипу прагне створити ситуацію, в якій вона перевершує всіх. I комплекс неповноцінності, i комплекс переваги відіграють для особистості компенсаторну роль, що дозволяє їй виконувати відповідні соціальні ролі й, за можливості, реалізовувати власний креативний потенціал у процесі адаптації до умов соціокультурного середовища.

Письмо для Косача постає унікальним психологічним феноменом самопізнання і пізнання світу, що часто супроводжується страхом смерті й бажанням iï подолати. На думку Ніли Зборовської, під час творення відбувається енергетичне перевантаження: «Психічна енергія в полі свідомості різко знижується, натомість активізуються глибинні енергетичні потоки неусвідомленого: водоспад міфологічних та архетипних (первинних) образів і символів виноситься 3 глибин душі» $[2,231]$. Вторгнення несвідомих творчих сил насамперед спонукає до оновлення та духовних змін у структурі окремої особистості та світу. Адже у психічних глибинах кожної людської істоти відбувається процес бродіння різноманітних бажань, які 
можуть ніколи не виявитися, але в екстремальних ситуаціях іноді вириваються назовні.

Карл Густав Юнг намагався вирішити питання дії компенсації та іiі поєднання з креативною діяльністю. Розробляючи власну модель організації психіки, швейцарський учений пішов значно далі від 3. Фройда, він структурува не тільки «позасвідоме», але й свідоме. Пацієнтам, які скаржилися на психічні розлади, він рекомендував намалювати те, що вони відчувають, за мірою здібностей, увівши поняття «терапевтичного методу». Згідно 3 теорією Юнга, тяжкий психічний стан, «позасвідоме» та «компенсація» мають спільну межу, за якою актуалізуються творчі здібності та постають джерелом розвитку креативності. Саме 3 проблематикою символів пов'язане розуміння К. Юнгом художньої творчості. Творчість Юнг, на відміну від 3. Фройда, розуміє не як викорінення індивідуального неврозу, дитячої психічної травми, а як пошук божества, до якого кожен іде своїм шляхом, відповідно до характеру своєї Самості.

Ймовірно, драматичний твір «Скорбна симфонія» був написаний в останнє десятиліття життя драматурга, коли він оцінював перспективи часу, власні творчі досягнення крізь призму своїх життєвих компромісів. Письмо допомагало Косачеві усвідомити свою Самість, виконувало компенсаторну функцію. Про час написання «Скорбної симфонії» якоюсь мірою свідчить уже сам факт, що текст зберігся в архівах в УВАНу [...]. В архівах збереглися насамперед рукописи останніх кільканадцяти років його життя. Але переконливішим показником часу написання драми $є$ важлива функція в тексті низки тем і мотивів, що посідають ключове місце в романі «Володарка Понтиди» (1987). На думку М. Р. Стеха, постать Бортнянського у драмі великою мірою постає своєрідним антиподом постаті протагоніста Юрія Рославця з роману «Володарка Понтиди», а відтак «Скорбна симфонія» - це також і комплементарне доповнення цього тексту «Володарки Понтиди».

У драматичному творі також ідеться про доробок митця, який досяг визнання коштом душевного і громадянського компромісу. Екзистенційно- 
межовий стан психіки митця виявляється у внутрішньому протистоянні двох генетично зумовлених типів реакцій: авантюрно-козацької та «повернення до себе». Українські філософи наголошують, що першоосновою української психіки є могутній козацький потяг до волі, який криється за зовнішньою потаємністю. Відчуження від самого себе було спричинене прагненням пізнати власну сутність. Самоідентифікація митця відбувається через примирення зі своїм минулим. У такий спосіб автор скеровує свій експеримент у русло вчення М. Гайдеггера, який стверджував: «Присутність у своєму фактичному бутті є завжди, і вона вже була. Явно чи ні, вона є своїм минулим. І це не лише так, що їі минуле тягнеться немов «за» нею, і вона має минуле як ще наявну властивість, що продовжує у ній діяти. Присутність «є» власним минулим згідно із способом свого буття...» $[5,20]$. За Ю. Косачем, самоідентичність стає неможливою без минулого.

Отримавши визнання та славу, композитор відчуває спустошення, втрачає духовність як головний чинник внутрішнього світу. Такі почуття, як любов, віра, відходять на другий план, поступаються місцем байдужості, страху, самотності. У драмі Косача відчуження творчої людини набуває форми внутрішньо-екзистенційної відокремленості від звичного та буденного, стану трагічного виходу з людського буття, дистанціювання від навколишнього світу 3 метою прагнення до екзистенційно розгорнутого буття. Бортнянський повністю відмовляється від спілкування 3 навколишнім середовищем та поринає у підсвідомі роздуми.

Отож, Ю. Косач не намагався відтворити біографічні реалії 3 життя митця. Ймовірніше, драматург (свідомо чи несвідомо) спроектував у творі власне «Я», власну кризу ідентичності, власні зовнішні й внутрішні фрустратори. Тим самим він дисоціював себе, намагаючись подивитися збоку на проблеми, із якими зіткнулися в еміграції, заради того, щоб не загубитись і не втратити власне «Я» десь у черговому таборі чи країні. 


\section{ЛІТЕРАТУРА}

1. Adler J. The Aesthetics of Magnetism: Science, Philosophy and Poetry in the Dialogue between Goethe and Schelling / J. Adler // The Third Culture: Literature and Science. London : Walter de Gruyter, 1998. - P. 66 - 102. - (European Cultures Studies in Literature and the Arts).

2. Зборовська Н. Код української літератури : проект психоісторії новітньої української літератури : [монографія] / Н. Зборовська. - К. : Академвидав, 2006. - 504 с.

3. Косач Ю. Скорбна симфонія [Текст] : драматична поема / Ю. Косач // Кур'єр Кривбасу. - 2012. - С. 279-321.

4. Стех М. Р. Дмитро Бортнянський у невідомій п`єсі Юрія Косача [Текст] / М. Р. Стех // Кур `р Кривбасу. - 2012. - № 266-267.

5. Х Хайдеггер М. Бытие и время / М. Хайдеггер ; [пер. с нем.]. - СПб. : Наука, 2002. $-452 \mathrm{c}$.

6. Юнг К. Г. Структура психики и процесс индивидуализации / К. Г. Юнг; [пер. Т. А. Ребеко]. - М.: «Наука», 1996. - 269 с.

\section{REFERENCES}

1. Adler J. The Aesthetics of Magnetism: Science, Philosophy and Poetry in the Dialogue between Goethe and Schelling, Walter de Gruyte, 1998, pp. 66 - 102 [In English].

2. Zborovska $N$. Kod ukrayinskoy literatury : proekt psihoistoriyi novitnoyi ukrayinskoyi literatury [Monografiya] [Code of Ukrainian literature: the project of psychological history of modern Ukrainian literature], Kyiv, Akademvidav, 2006, 504 p [In Ukrainian].

3. Kosach $Y u$. Skorbna simfoniya: dramatichna poema [The sorrowful symphony: dramatic poem], Kur'yer Kryvbasu [Courier of Kryvbas], 2012, pp. 122 - 186 [In Ukrainian].

4. Steh M. R. Dmitro Bortnyanskiy u nevidomiy p`esi Yuriya Kosacha [Dmytro Bortnyanskyi in unknown play of Yury Kosach], Kur'yer Kryvbasu [Courier of Kryvbas], 2012, pp. 266 - 267 [In Ukrainian].

5. Heidegger M. Byitie i vremya [Being and time], Sankt-Peterburg, Nauka, 2002, 452 p [In Russian].

6. Jung K. Struktura psihiki i protsess individualizatsii [Structure of psychic and process of personalization], Moskva, Nauka, 1996, 269 p [In Russian].

\section{АННОТАЦИЯ}

Мария Реутова. Проблема «автор-герой» в контексте структурирования модели авторского сознания (на примере драмы Юрия Косача «Скорбная симфония»).

Рассмотрены особенности проблемы самоидентичности в драме Юрия Косача «Скорбная симфония». В частности, внимание сосредоточено на взаемоиерархичности исторической памяти и исторического сознания, их консолидирующем смысле в формировании идентичности украинской нации в условиях эмиграции. Отмечено, что формой авторской идентичности в творческой деятельности и идентичности читателя в процессе рецепции является образ героя, который выступает как образная картина и проект воображаемой личности автора.

Ключевые слова: автор, герой, драма, идентичность, сознание, текст. 


\begin{abstract}
Mariia Reutova. The problem of «the author-hero» in the context model structuring author's consciousness («Sorrowful Symphony» by Yuriy Kosach).

The article deals with the peculiarities of the national identity problem in artistic works by Yuriy Kosach of DP period. Namely, the attention is paid to the mutual hierarchy of historical memory and historical consciousness, their role of consolidation in Ukrainian national identity in emigration. In the basis of analysis there are mythological tendency «hero-antihero», complex of memory and author's strategies for dealing with territorial and political. It is noted that the image of the hero who acts as a figurative picture and the project of the author's imaginary personality is the form of the author's identity in the creative activity and identity of the reader in the process of recept. Yuriy Kosach didn't try to recreate the biographical reality of the life of the artist. Likely playwright (consciously or unconsciously) designed to create their own "I", its own identity crisis, their internal and external frustratory. The author tried to look sideways to the problems faced with in exile, in order not to get lost and not lose their own "I" somewhere in the next camp or country.

Key words: author, character, drama, consciousness, text.
\end{abstract}

